\title{
Implementasi Model Bamboo Dancing Berbantu Media Name Card dalam Meningkatkan Hasil Belajar Kognitif Sekolah Dasar
}

\author{
Charolina Maya Putri ${ }^{*}$, A.Y Soegeng Ysh ${ }^{2}$, Mira Azizah $^{3}$ \\ 1,2,3 PGSD Fakultas Ilmu Pendidikan Universitas PGRI Semarang
}

A R T I C L E I N F O

Article history:

Received 19 August 2019

Received in revised form

30 September 20189

Accepted 10 October 2019

Available online 29

November 2019

\section{Kata Kunci:}

model bamboo dancing,

media name card, hasil

belajar siswa.

Keywords:

bamboo dancing model,

name card media, student learning outcomes

\begin{abstract}
A B S T R A K
Tujuan penelitian ini untuk mengetahui keefektifan model pembelajaran bamboo dancing berbantu media name card terhadap hasil belajar IPS siswa kelas IV SDN 01 dan SDN 03 Puri Pati. Jenis penelitian ini adalah penelitian kuantitatif dengan desain pretest-posttest control group desain. Populasi penelitian ini adalah siswa kelas IV SDN 01 dan SDN 03 Puri yang masing-masing berjumlah 20 siswa dengan mengunakan teknik simple random sampling. Data dalam penelitian ini didapatkan dari observasi, tes dan dokumentasi. Berdasarkan perhitungan diperoleh $t_{\text {hitung }}$ sebesar 2,625 sedangkan $t_{\text {tabel }}$ dengan $\mathrm{db}=$ $\mathrm{N}-1=20-1=19$, dan taraf signifikan 0,05 sebesar 2,024. Karena $\mathrm{t}_{\text {hitung }}$ $>t_{\text {tabel }}$ yaitu 2,625 > 2,024 maka $\mathrm{H}_{0}$ ditolak dan Ha diterima, sehingga dapat dikatakan bahwa model pembelajaran bamboo dancing berbantu media name card efektif dibandingkan dengan model pembelajaran konvensional. Terhadap hasil belajar IPS siswa kelas IV SDN 03 Puri Pati sebagai kelas eksperimen. Berdasarkan hasil penelitian ini saran yang dapat disimpulkan bahwa model pembelajaran bamboo dancing berbantu media name card dapat digunakan sebagai salah satu alternative guru dalam mengajar.
\end{abstract}

A B S T R A C T

The purpose of this study was to determine the effectiveness of the bamboo dancing learning model assisted by name card media on the social studies learning outcomes of Grade IV SDN 01 and SDN 03 Puri Pati students. This type of research is a quantitative study with a pretest-posttest control group design. The population of this study was students in grade IV SDN 01 and SDN 03 Puri, each of which numbered 20 students using simple random sampling techniques. The data in this study were obtained from observations, tests and documentation. Based on the calculation, the tcount is 2,625 while the table with $d b=N-1=20-1=19$, and the significant level of 0.05 is 2.024. Because tcount> ttable is 2,625>2,024, HO is rejected and $\mathrm{Ha}$ is accepted, so it can be said that the bamboo dancing learning model assisted by the name card media is effective compared to conventional learning models towards social studies learning outcomes of fourth grade students at SDN 03 Puri Pati as an experimental class. Based on the results of this study the suggestion can be concluded that the bamboo dancing learning model assisted by the name card media can be used as an alternative teacher in teaching. 


\section{Pendahuluan}

Pendidikan merupakan salah satu komponen penentu masa depan suatu bangsa. Berbagai upaya sudah digunakan untuk memajukan pendidikan mulai dari mengembangkan kurikulum sampai cara mengajar yang semakin lama semakin disempurnakan. Pendidikan menjadi komponen vital bagi kemajuan suatu bangsa, jika pendidikan disuatu bangsa maju maka turut maju pula sumber daya manusia bangsa tersebut. Namun sebaliknya, jika pendidikan suatu bangsa lemah, maka akan lemah pula sumber daya manusia bangsa tersebut.

Soegeng (2018: 63) mengemukakan pendidikan ialah urusan manusia, hanya manusialah yang memiliki pendidikan subjek dan objek pendidikan adalah manusia.Yang mendidik adalah manusia, yang dididik juga manusia. Pendidikan merupakan komunikasi cara berada manusia yaitu komunikasi yang otentik cara berada manusia kepada manusia muda, agar supaya dimiliki, dilanjutkan dan disempurnakan. Komunikasi itu terlaksana antara pendidik (generasi tua, orang dewasa) dan anak didik (generasi muda, orang yang belum dewasa).

Pembelajaran di sekolah dasar menyajikan beberapa mata pelajaran diantaranya adalah Ilmu Pengetahuan Sosial. Menurut Susanto (2013: 137). IPS, adalah ilmu pengetahuan yang mengkaji berbagai disiplin ilmu sosial dan humaniora serta kegiatan dasar manusia yang dikemas secara ilmiah dalam rangka memberi wawasan dan pemahaman yang mendalam kepada peserta didik, khususnya ditingkat dasar dan menengah.Luasnya kajian IPS ini mencakup berbagai kehidupan yang beraspek majemuk baik hubungan sosial, ekonomi, psikologi, budaya, sejarah, maupun politik, semuanya dipelajari dalam ilmu sosial ini.

Pembelajaran IPS yang masih jarang menggunakan kegiatan diskusi, bukan merupakan masalah utama dalam proses pembelajaran di kelas. Ada berbagai macam masalah yang sering dialami oleh guru IPS di dalam kelas, hal ini dapat kita lihat dari teks wawancara yang telah kita lakukan di sekolah dasar sebelum kita melakukan penelitian ( lampiran 48 halaman 208)

Berdasarkan observasi yang dilakukan di kelas IV SDN Puri 03 Pati, dan kelas IV SDN Puri 01 Pati menunjukkan bahwa pelajaran IPS yang mengembangkan kemampuan untuk berpikir kritis siswa kurang optimal dalam proses pembelajaran di dalam kelas. Hal ini terlihat pada saat guru memberikan pertanyaan, siswa hanya diam belum berani mengutarakan pendapatnya dan siswa cenderung tidak bisa menjawab pertanyaan yang di berikan oleh guru di akhir pembelajaran.Siswa cederung asik berbicara dengan teman sebangku, bermain uang kertas dan mengambar di buku tulisnya.Sehingga siswa tidak dapat berpikir dan belum mengeluarkan ide-ide yang di pikirkanya demgan baik.

Berdasarkan masalah tersebut perlu adanya strategi pembelajaran yang mampu meningkatkan hasil belajar dan menutup permasalah yang terjadi di atas. Maka dari itu peneliti menerapkan model pembelajaran bamboo dancing, atau bisa disebut juga tari bambu untuk melatih siswa untuk berkomunikasi dengan teman lebih baik, yang biasanya tidak aktif dalam pembelajaran, dengan mengunakan model ini siswa menjadi lebih aktif karena semua berperan di dalam kelas pada saat proses pembelajaran berlangsung.

Dinamakan model bamboo dancing karena siswa belajar dan saling berhadapan dengan model yang mirip seperti dua potong bambu yang digunakan dalam tari bambu Filiphina yang popular di beberapa daerah di Indonesia. Strategi ini memungkinkan siswa saling berbagi informasi pada waktu yang bersamaan. (Huda, 2017: 250). Selain model, media juga ikut serta membantu dalam proses pembelajaran.

Manfaat media secara umum mempunyai kegunaan, untuk memperjelas pesan agar tidak terlalu verbalitas, mengatasi keterbatasan ruang, waktu tenaga dan daya indera, menimbulkan gairah belajar, interaksi lebih langsung anatara murid dan sumber belajar, memungkinkan anak belajar mandiri sesuai dengan bakat dan kemampun visual dan kinestiknya, memberi rangsangan yang sama, mempersamakan pengalaman dan menimbulkan persepsi yang sama. (Susilana, $2017: 9$ ).

Penggunaan kartu membantu siswa menjadi lebih termotivasi untuk belajar, tanpa harus terbebani oleh situasi belajar yang kaku dan membosankan. Siswa diajak belajar sambil bermain untuk menghilangkan kejenuhan mereka, tanpa mengabaikan konsentrasi dalam belajar, sehingga konsep dapat ditemukan sendiri oleh siswa dan hasil belajar akan meningkat.

Guru dapat menggunakan media name card. Name card adalah kartu yang berisi materi, pertanyaan, jawaban dan nama dari masing-masing siswa yang dapat dipecahkan dan rasa ingin tahu siswa. Di sini peneliti memanfaatkan media tersebut yang memuat tentang pertayaan-pertayaan yang dapat merubah siswa untuk lebih dapat berpikir kritis lagi.Name card dijadikan media yang menarik perhatian siswa untuk berpikir kritis. Karena pada media ini akan membuat rasa ingin tahu siswa terhadap informasi yang akan disampaikan 
Berdasarkan penelitian Sativa (2012 :2) dalam jurnal penggunaan media kartu untuk meningkatkan hasil belajar geometri siswa kelas XI IPS 1 SMA Kolombo Sleman Yogyakarta, penggunaan media kartu dapat meningkatkan hasil belajar geografi. Tanggapan siswa terhadap media kartu yang digunakan dinilai sangat baik pada masing-masing indikator.Siswa menjadi tidak jenuh, dan lebih mudah memahami materi. Berdasarkan peneliti melakukan penelitian tentang implementasi model pembelajaranbamboo dancing berbantu media name card dalam meningkatkan hasil belajar kognitif

\section{Metode}

Metode penelitian yang digunakan dalam penelitian ini adalah metode eksperimen. Langkahlangkah yang digunakan pada penelitian ini adalah memberikan perlakuan berbeda antara kelas kontrol dan kelas eksperimen.pada kelas kontrol akan menggunakan model example non example, sedangkan pada kelas eksperimen menggunakan model bamboo dancing berbantu media name card. Dalam hal ini yang berbeda adalah pada model pelajaran yang digunakan. Setelah diberikan perlakuan yang berbeda akan dilaksanakan posttest pada akhir pembelajaran. Peneliti membandingkan hasil yang diperoleh siswa untuk melihat seberapa jauh perbedaan hasil dari posstest. Analisis ini akan menunjukkan bahwa model yang diterapkan dapat efektif atau tidak

\section{Hasil dan Pembahasan}

Pada hasil nilai pretest dapat dilihat pada tabel 1

Tabel 1. Nilai Pretest Kelas Kontrol dan Kelas Eksperimen

\begin{tabular}{lll}
\hline Kriteria & Kelas Kontrol & Kelas Eksperimen \\
\hline Rata-rata & 55,95 & 64,4 \\
\hline Siswa Tuntas & 1 & 3 \\
\hline Siswa Tidak Tuntas & 19 & 17 \\
\hline Nilai Tertinggi & 75 & 80 \\
\hline Nilai Terendah & 28 & 44 \\
\hline
\end{tabular}

Sumber: Analisis Hasil Pretest 2019

Berdasarkan tabel di atas diketahui bahwa pada kelas kontrol terdapat 1 siswa yang mencapai KKM sedangkan pada kelas eksperimen terdapat 3 siswa yang mencapai KKM. Nilai tertinggi pada kelas kontrol 75, nilai terendah pada kelas kontrol 28 dengan rata-rata 55,95. Sedangkan pada kelas eksperimen nilai tertinggi diperoleh 80 dan nilai terendah diperoleh sebesar 44, dengan nilai rata-rata sebesar 64,4. Nilai kriteria ketuntasan minimal (KKM) yang telah ditetapkan oleh sekolah khususnya siswa kelas IV SDN 01 Puri dan SDN 03 Puri Pati yaitu 75. Berikutnya hasil pretest dijadikan sebagai pembanding untuk mengetahui kemampuan awal dari siswa SDN 01 Puri dan SDN 03 Puri Pati.

Berdasarkan hasil rata-rata nilai pretest kelas eksperimen dan kontrol hanya selisih 6,65 , walau terdapat selisih hasil pretest tetapi perbedaan tersebut tidak signifikan sehingga dapat disimpulkan bahwa kemampuan awal siswa SDN 01 Puri dan SDN 03 Puri Pati sama. Selanjutnya nilai yang digunakan dalam penelitian ini adalah dari hasil posttest dari kelas eksperimen dan kelas kontrol. Sebelum mendapat nilai posttest siswa diberikan proses pembelajaran kelas kontrol selama 2 kali pertemuan dan kelas eksperimen 2 kali pertemuan. Kelas kontrol dalam proses pembelajaran IPS menggunakan model example non example dengan metode diskusi, tanya jawab dan penugasan. Sementara kelas eksperimen dalam proses pembelajaran IPS menggunakan model bamboo dancing berbantu media name card sesuai dengan materi yang diajarkan. Berikut ini adalah nilai posttest kelas kontrol dan kelas eksperimen.

Tabel 2. Nilai Posttest Kelas Kontrol dan Kelas Eksperimen

\begin{tabular}{llc}
\hline Kriteria & Kontrol & Eksperimen \\
\hline Rata-rata & 73,2 & 83,9 \\
Siswa Tuntas & 14 & 18 \\
Siswa Tidak Tuntas & 6 & 2 \\
Nilai Terendah & 44 & 46 \\
Nilai Tertinggi & 92 & 100 \\
\hline
\end{tabular}


Berdasarkan tabel di atas nilai posttest di atas diketahui bahwa kelas kontrol telah mencapai ketuntasan belajar sebanyak 14 siswa dan kelas eksperimen sebanyak 18 siswa Siswa yang tidak tuntas pada kelas kontrol sebanyak 6 dan kelas eksperimen sebanyak 2 siswa. Nilai kriteria ketuntasan minimal (KKM) yang telah ditetapkan oleh sekolah khususnya siswa kelas IV SDN 01 Puri dan SDN 03 Puri Pati yaitu 75. Berdasarkan hasil posttest diatas diperoleh nilai rata-rata kelas kontrol 73,2 dan nilai rata-rata pada kelas eksperimen 83,9. Selisih nilai rata-rata kelas kontrol dan kelas eksperimen sebanyak 10,7. Adapun perolehan nilai terendah pada kelas kontrol 44 dan nilai terendah kelas eksperimen adalah 46, sedangkan nilai tertinggi kelas kontrol 92 dan nilai tertinggi kelas eksperimen sebesar 100.

Uji normalitas awal (pretest) digunakan untuk mengetahui data yang akan dianalisis berdistribusi normal atau tidak normal setelah diberilakan perlakuan menggunakan model pembelajaran bamboo dancing berbantu media pembelajaran name card. Hal ini dilakukan untuk menemukan uji statistik selanjutnya. Rumus yang digunakan uji Liliefors, dengan ketentuan bahwa kelompok berdistribusi normal jika memenuhi kriteria Lo <Ltabel yang diukur pada taraf signifikan 0,05.

Tabel 3. Analisis Uji Normalitas Data Awal

\begin{tabular}{|c|c|c|c|c|c|}
\hline No & Kelas & $\mathrm{N}$ & $\mathrm{L}_{0}$ & $\mathrm{~L}_{\text {tabel }}$ & Kesimpulan \\
\hline 1 & Eksperimen & 20 & 0,116 & 0,190 & Normal \\
\hline 3 & Kontrol & 20 & 0,109 & 0,190 & Normal \\
\hline
\end{tabular}

Sumber: Analisis Uji Normalitas Data Awal

Berdasarkan Tabel 3 diketahui bahwa hasil perhitungan dengan menggunakan langkah-langkah uji Liliefors terlihat nilai $\mathrm{L}_{0}$ untuk data kelompok eksperimen sebesar $0,116<\mathrm{L}_{\text {tabel }}(0,190)$ dan untuk kelompok kontrol sebesar $0,109<\mathrm{L}_{\text {tabel }}(0,190)$ yang berarti bahwa kedua data berdistribusi normal.Uji normalitas akhir (posttest) digunakan untuk mengetahui data yang akan dianalisis berdistribusi normal atau tidak normal setelah diberilakan perlakuan menggunakan model pembelajaran bamboo dancing berbantu media pembelajaran name card.

Tabel 4. Analisis Uji Normalitas Data Akhir

\begin{tabular}{llllll}
\hline No & Kelas & $\mathrm{N}$ & $\mathrm{L}_{0}$ & $\mathrm{~L}_{\text {tabel }}$ & Kesimpulan \\
\hline 1 & Eksperimen & 20 & 0,141 & 0,190 & Normal \\
3 & Kontrol & 20 & 0,172 & 0,190 & Normal \\
\hline
\end{tabular}

Sumber: Analisis Uji Normalitas Data Akhir

Hasil perhitungan di atas dengan menggunakan langkah-langkah uji Liliefors terlihat bahwa nilai $\mathrm{L}_{0}$ untuk data kelompok eksperimen sebesar 0,141< $\mathrm{L}_{\text {tabel }}(0,190)$ dan untuk kelompok kontrol sebesar $0,172<L_{\text {tabel }}(0,190)$ yang berarti bahwa kedua data berdistribusi normal, sehingga statistik selanjutnya untuk pengujian hipotesis dapat digunakan statistik parametrik.

Uji homogenitas dilakukan untuk mengetahui apakah kelompok eksperimen dan kontrol memiliki varians yang sama atau tidak.Adapun perhitungan uji homogenitas data akhir diperoleh hasil sepertipada tabel berikut.

Tabel 5. Uji Homogenitas Pretest

\begin{tabular}{ll}
\hline Keterangan & Nilai \\
\hline$F_{\text {hitung }}$ & 1,927 \\
\hline$F_{\text {tabel }}$ & 2,168 \\
\hline
\end{tabular}

Sumber: analisis uji homogenitas pretest tahun 2019

Berdasarkan hasil perhitungan dengan $\alpha=5 \%$ dan $\mathrm{dk}=19$ diperoleh nilai $\mathrm{F}_{\text {hitung }}=1,927$ dengan $\mathrm{F}_{\text {tabel }}=2.168$. Karena $\mathrm{F}_{\text {hitung }}<\mathrm{F}_{\text {tabel }}$ yaitu $1,927<2,168$ maka $\mathrm{H}_{\mathrm{a}}$ ditolak dan $\mathrm{H}_{0}$ diterima artinya kedua kelompok kelas sampel berasal dari populasi yang homogen.

Data penelitian dengan sampel lebih dari satu harus dilakukan uji homogenitas untuk mengetahui kelas yang dijadikan sampel berasal dari populasi yang homogen atau tidak. Hipotesisnya dapat dilihat pada tabel berikut ini; 
Tabel 6. Uji Homogenitas Posttest

\begin{tabular}{lr}
\hline Keterangan & Nilai \\
\hline $\mathrm{F}_{\text {hitung }}$ & 0,985 \\
\hline $\mathrm{F}_{\text {tabel }}$ & 2,168 \\
\hline
\end{tabular}

Sumber: analisis uji homogenitas posttest tahun 2019

Berdasarkan hasil perhitungan dengan $\alpha=5 \%$ dan $\mathrm{dk}=19$ diperoleh nilai $\mathrm{F}_{\text {hitung }}=0,985$ dengan $\mathrm{F}_{\text {tabel }}=2.168$. Karena $\mathrm{F}_{\text {hitung }}<\mathrm{F}_{\text {tabel }}$ yaitu $0,985<2,168$ maka $\mathrm{H}_{\mathrm{a}}$ ditolak dan $\mathrm{H}_{0}$ diterima artinya kedua kelompok kelas sampel berasal dari populasi yang homogen.

Pengaruh model pembelajaran dapat diketahui dengan menguji KKM. Data yang diperoleh dari hasil belajar sebelum dan sesudah diberi perlakuan dihitung dengan menggunakan Uji-t. Uji- $t$ digunakan untuk mengetahui ketuntasan hasil belajar. Dengan kriteria jika $t_{\text {hitung }}>t_{\text {tabel }}$ maka $\mathrm{H}_{\mathrm{a}}$ diterima dan $\mathrm{H}_{0}$ ditolak, jika $t_{\text {hitung }}<t_{\text {tabel }}$ maka $\mathrm{H}_{\mathrm{a}}$ ditolak dan $\mathrm{H}_{0}$ diterima. Berdasarkan perhitungan diperoleh $\mathrm{t}_{\text {hitung }}$ sebesar 2,625 sedangkan $t_{\text {tabel }}$ dengan $\mathrm{db}=\mathrm{N}-1=20-1=19$, dan taraf signifikan 0,05 sebesar 2,024. Karena $t_{\text {hitung }}$ $>t_{\text {tabel }}$ yaitu 2,625 > 2,024 maka $\mathrm{H}_{0}$ ditolak dan $\mathrm{H}_{\mathrm{a}}$ diterima. Sehingga dapat dikatakan bahwa model pembelajaran bamboo dancing berbantu media name card berpengaruh terhadaphasil belajar IPS siswa kelas IV SDN 01 Puri dan SDN 03 Puri Pati

Untuk mengetahui tercapai atau tidaknya ketuntasan belajar siswa kelas IV SDN 01 Puri dan SDN 03 Puri Pati pada materi pahlawan pada pelajaran IPS dengan menerapkan model bamboo dancing berbantu media name card, maka dilakukan perhitungan sebagai berikut:

Tabel 7. Ketuntasan Belajar Kelas

\begin{tabular}{llrrr}
\hline \multirow{2}{*}{ Kelas } & $\begin{array}{l}\text { Persentase } \\
\text { Tuntas }\end{array}$ & Tidak Tuntas & $\begin{array}{l}\text { Tingkat Minimal } \\
\text { Ketuntasan }\end{array}$ & Keterangan \\
\cline { 1 - 3 } Eksperimen & $18(90 \%)$ & $2(10 \%)$ & $75 \%$ & Tuntas \\
Kontrol & $14(70 \%)$ & $6(30 \%)$ & & Tidak Tuntas \\
\hline
\end{tabular}

Berdasarkan Tabel 7 dapat disimpulkan bahwa kelas eksperimen dapat dikatakan tuntas secara klasikal sedangkan kelas kontrol dikatakan tidak tuntas secara klasikal. Jadi dapat disimpulkan bahwa model bamboo dancing berbantu media name card terhadap hasil belajar siswa kelas eksperimen tuntas secara klasikal.

Berdasarkan data yang diperoleh, diketahui bahwa pada kelas kontrol terdapat 1 siswa yang mencapai KKM sedangkan pada kelas eksperimen terdapat 3 siswa yang mencapai KKM. Kriteria ketuntasan minimun (KKM) yang telah ditetapkan oleh SDN 01 Puri dan SDN 03 Puri Pati Tahun Pelajaran 2018/2019 yaitu 75. Nilai tertinggi pada kelas kontrol 75, nilai terendah pada kelas kontrol 28 dengan rata-rata 55,95. Sedangkan pada kelas eksperimen nilai tertinggi diperoleh 80 dan nilai terendah diperoleh sebesar 44, dengan nilai rata-rata sebesar 64,4. Berikutnya hasil pretest dijadikan sebagai pembanding untuk mengetahui kemampuan awal dari siswa SDN 01 Puri dan SDN 03 Puri Pati..Perhitungan selengkapnya dapat dilihat pada lampiran 28 halaman 184.

Berdasarkan hasil rata-rata nilai pretest kelas eksperimen dan kontrol hanya selisih 6,65 , walau terdapat selisih hasil pretesttetapi perbedaan tersebut tidak signifikan sehingga dapat disimpulkan bahwa kemampuan awal siswa SDN 01 Puri dan SDN 03 Puri Pati sama.

Berdasarkan hasil posttest diatas diperoleh nilai rata-rata kelas kontrol 73,2 dan nilai rata-rata pada kelas eksperimen 83,9. Selisih nilai rata-rata kelas kontrol dan kelas eksperimen sebanyak 10,7. Adapun perolehan nilai terendah pada kelas kontrol 44 dan nilai terendah kelas eksperimen adalah 46 , sedangkan nilai tertinggi kelas kontrol 92 dan nilai tertinggi kelas eksperimen sebesar 100. Perhitungan selengkapnya dapat dilihat pada lampiran 27 halaman 183.

Penelitian ini menggunakan teknik analisis data dengan menggunakan Uji-t. Uji normalitas dan uji homogenitas dilakukan untuk mengetahui hasil ketutasan hasil belajar.Uji normalitas awal (pretest) digunakan untuk mengetahui data yang akan dianalisis berdistribusi normal atau tidak normal sebelum diberi perlakuan. Hal ini untuk menentukan uji statistik selanjutnya. Rumus uji Lilieforsmenentukan bahwa suatukelompok berdistribusi normal jika memenuhi kriteria $\mathrm{L}_{\mathrm{o}}<\mathrm{L}_{\text {tabel }}$ yang diukur pada taraf signifikan 0,05

Hasil perhitungan di atas dengan menggunakan langkah-langkah uji Liliefors terlihat bahwa nilai $\mathrm{L}_{0}$ untuk data kelompok eksperimen sebesar $0,116<\mathrm{L}_{\text {tabel }}(0,190)$ dan untuk kelompok kontrol sebesar 
$0,109<L_{\text {tabel }}(0,190)$ yang berarti bahwa keduadata berdistribusi normal. Perhitungan selengkapnya dapat dilihat pada lampiran 29 halaman 185

Uji normalitas akhir diuji dengan menggunakan data nilai posttest pada kelas eksperimen, diperoleh nilai $\mathrm{L}_{0}$ untuk data kelompok eksperimen sebesar $0,141<\mathrm{L}_{\text {tabel }}(0,190)$ dan untuk kelompok kontrol sebesar $0,172<L_{\text {tabel }}(0,190)$ yang berarti bahwa kedua data berdistribusi normal, sehingga statistik selanjutnya untuk pengujian hipotesis dapat digunakan statistik parametrik.Dengan demikian data dari nilai posttest pada kedua kelas berasal dari data yang berdistribusi normal.Setelah dilakukan uji normalitas, kemudian dilakukan uji homogenitas awal untuk mengetahui data berasal dari populasi yang homogen atau tidak. Perhitungan selengkapnya dapat dilihat pada lampiran 34 halaman 191

Uji homogenitas awal diuji dengan menggunakan data pretest, berdasarkan hasil perhitungan dengan $\alpha=5 \%$ dan dk=19 diperoleh nilai $F_{\text {hitung }}=1,927$ dengan $F_{\text {tabel }}=2.168$. Karena $F_{\text {hitung }}<F_{\text {tabel }}$ yaitu 1,927 $<2,168$ maka $\mathrm{H}_{\mathrm{a}}$ ditolak dan $\mathrm{H}_{0}$ diterima artinya kedua kelompok kelas sampel berasal dari populasi yang homogen.Sedangkan uji homogenitas akhir diuji dengan menggunakan data posttest, berdasarkan hasil perhitungan dengan $\alpha=5 \%$ dan dk=19 diperoleh nilai $F_{\text {hitung }}=0,985$ dengan $F_{\text {tabel }}=2.168$. Karena $F_{\text {hitung }}<F_{\text {tabel }}$ yaitu $0,985<2,168$ maka $\mathrm{H}_{\mathrm{a}}$ ditolak dan $\mathrm{H}_{0}$ diterima artinya kedua kelompok kelas sampel berasal dari populasi yang homogen. Perhitungan selengkapnya dapat dilihat pada lampiran 32 halaman 189

Uji- $t$ ini dilakukan untuk menguji hasil belajar posttest pada kelas kontrol yang diberikan perlakuan dengan menggunakan model example non example dan kelas eksperimen dengan menggunakan model

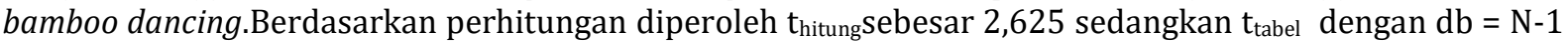
$=20-1=19$, dan taraf signifikan 0,05 sebesar 2,024. Karena $t_{\text {hitung }}>t_{\text {tabel }}$ yaitu 2,625 $>2,024$ maka H0 ditolak dan Ha diterima. Sehingga dapat dikatakan bahwa model pembelajaran bamboo dancing berbantu media name card berpengaruh terhadap hasil belajar IPS siswa kelas IV SDN 01 Puri dan SDN 03 Puri Pati Perhitungan selengkapnya dapat dilihat pada lampiran 39 halaman 197

Uji hasil belajar dilakukan untuk mengukur kemampuan siswa dalam mencapai tujuan pembelajaran, pada hasil uji ketuntasan belajar individu diperoleh tingkat ketuntasan kemampuan siswa mencapai nilai diatas KKM 75 sebesar 88\%. Kemudian pada uji ketuntasan klasikal diperoleh jumlah siswa yang menguasai pembelajaran diatas nilai KKM mencapai 75\%.Karena tingkat ketuntasan siswa bisa mencapai lebih dari 75\%, maka model bamboo dancingefektif terhadap hasil belajar IPS pada siswa kelas eksperimen, hal ini dapat kita lihat berdasarkan hasil posttest yang dilakukan oleh peneliti yang signifikan antara kelas eksperimen dan kelas kontrol.

Berdasarkan paparan diatas dan data yang diperoeh maka dapat disimpulkan bahwa terdapat perbedaan yang signifikan atau nyata hasil belajar kelas eksperimen yang menggunakan model bamboo dancing dengan kelas kontrol yang menggunakan model example non example. Penelitian sebelumnya pernah dilakukan oleh Ariyani, (2018) dengan judul "Kefektifan model pembelajaran bamboo dancing berbantu kartu pintar terhadap kemampuan berfikir kritis pada mata pelajaran IPA seswa kelas IV SDN Wanusobo Jepara".Jenis penelitian yang dilakukan adalah Penelitian Tindakan Kelas dengan subyek penelitian adalah siswa kelas IV tahun pelajaran 2017/2018 dengan jumlah 24 orang.Jenis data bersifat kuantitatif yang diperoleh melalui observasi dan pemberian tes.Penelitian ini dilakukan dalam dua siklus.Secara umum, hasil penelitian ini menunjukkan terjadinya peningkatan pada hasil belajar pada mata pelajaran IPA.Dengan demikian dapat disimpulkan bahwa model bamboo dancing dapat diterapkan pada siswa kelas Kelas IV SDN Wanuboso Jepara.

Hasil belajar dengan mengunakan model bamboo dancing terhadap hasil belajar IPS kelas IV dikelas eksperimen yang dilakukan di SDN 03 Puri Pati dikatakan efektif dikarenakan dapat mencapai ketuntasan belajar siswa, dengan nilai rata-rata 75 sebagai KKM (Ketuntasan Belajar Minimal). Pembelajaran IPS tema pahlawanku subtema 3 "sikap kepahlawanan" pada pembelajaran 1 dan pembelajaran 5 dilakukan pada kelas eksperimen dan kelas kontrol. Pada kelas kontrol diterapkan model pembelajaran example non example sedangkan pada kelas eksperimen diterapkan model bamboo dancing berbantu media name card. Pada kedua kelas tersebut terdapat hasil belajar yang berbeda kelas kontrol yang mengunakan model example non example hanya siswa yang memperhatikan guru saat menyampaikan pembelajaran saja yang bisa menjawab pertanyaan-pertanyaan yang di berikan oleh guru, sedangkan di kelas eksperimen yang mengunakan model pembelajaran bamboo dancing berbantu media name card hampir semua siswa dikatan dapat menjawab pertanyaan guru karena model bamboo dancing berbantu name card bersifat bertukar pikiran antar satu siswa ke siswa yang lain. Selain itu terdapat faktor lain yang mempengaruhi proses pembelajaran tersebut antara lain minat siswa dalam mengikuti pembelajaran. Kelas kontrol yang mengunakan model example non example siswa yang mempuyai keberanian lebih mereka yang lebih cenderung aktif, sedangkan pada kelas eksperimen yang mengunakan model pembelajaran bamboo dancing berbantu media name card seluruh siswa lebih cederung aktif karena mereka belajar sambil bermain, dan siswa sekolah dasar lebih cenderung suka bermain disini peneliti menggajak siswa bermain sambil belajar. 
Pada kegiatan pembelajaran guru menggunakan media kartu berupa name card atau kartu nama. Peneliti mengunakan media name card supaya siswa dapat membedakan antara kartu satu dengan kartu yang lain, memudahkan siswa untuk tidak mengulang-ulang soal yang di terima, untuk menunjang kegiatan belajar, untuk menarik perhatian siswa terhadap materi yang diberikan oleh guru, dan untuk menjadikan belajar siswa menjadi lebih semangat dan antusias. Dengan hasil belajar siswa yang meningkat maka pembelajaran dengan model bamboo dancing.

Berdasarkan uraian di atas maka dapat diketahui bahwa model bamboo dancingberbantu media name card dapat meningkatkan hasil belajar IPS siswa dibandingkan dengan model example non example dengan perbedaan yang signifikan. Berdasarkan hal tersebut dapt disimpulkan model bamboo dancingberbantu media name card efektif terhadap hasil belajar IPS pada siswa kelas eksperimen yang dilakukan dikelas IV SDN 03 Puri Kabupaten Pati.

\section{Simpulan Dan Saran}

Berdasarkan data hasil penelitian, analisis, dan pembahasan hasil penelitian, maka peneliti membuat kesimpulan bahwa proses pembelajaran mengunakan model bamboo dancing berbantu media name card efektif terhadap hasil belajar IPS terhadap siswa kelas IV SDN 01 dan SDN 03 Puri Pati. Hal ini dapat dibuktikan dengan uji hipotesis dengan menggunakan uji banding (Uji-t) diperoleh $t_{\text {hitung }}=2,625$. Kemudian harga $t_{\text {hitung }}$ dibandingkan dengan harga $t_{\text {tabel. }} T_{\text {tabel }}$ ditentukan dengan $d k=n_{1}+n_{2}-2=38$ dan taraf $\alpha=0,05$ adalah 2,024. Berdasarkan kriteria pengujian bahwa $H_{a}$ ditolak dan $H_{0}$ diterima jika $t_{\text {hitung }}$ lebih kecil dari $t_{\text {tabel. }}$ Ternyata didapati $t_{\text {hitung }}$ lebih besar dari $t_{\text {tabel }}$ yaitu $2,625<2,024$. Maka dapat disimpulkan bahwa $\mathrm{H}_{\mathrm{a}}$ ditolak dan $\mathrm{H}_{0}$ diterima, ketuntasan belajar pada kelas eksperimen lebih tinggi daripada kelas kontrol.Hal ini dibuktikan dengan nilai pretest dengan ketuntasan $15 \%$ menjadi $90 \%$ pada nilai posttest.Peningkatan nilai pretest pada kelas eksperimen dari persentase sebesar 15\% naik sebesar $75 \%$ menjadi $90 \%$ persentase dari nilai posttest.

\section{Daftar Rujukan}

Arikunto, Suharsimi.2013.Prosedur Penelitian Suatu Pendekatan Praktik.Jakarta: Rineka Cipta

Arsyad, Azhar. 2014. Media Pembelajaran .Jakarta: rajagrafindo persada.

Ariyani, Cika Oktafiana. 2018. "Keefektifan Model Pembelajaran Bamboo Dancing Berbantu Media Kartu Pintar Terhadap Kemampuan Berfikir Kritis Pada Mata Pelajaran IPASiswa Kelas IV SDN Wanusobo Jepara". Skripsi : Universitas PGRI Semarang.

Candani, Dea Wahyu. 2015. "Upaya Meningkatkan Hasil Belajar IPS Melalui Model Pembelajaran Kooperatif Tipe Tari Bambu Kelas V Pada SDN 5 Pahandut PalangkarayaTahunPelajaran2014/2015".http://perpus.umpalangkaraya.ac.id/digilib/files/disk1/ 4/123-dfadf-deawahyuca-180-1-skripsi-i.pdf. Diakses pada tanggal 24 September 2018.

Huda, Miftahul. 2014. Model-Model Pengajaran dan Pembelajaran Isu-Isu Metodis dan Paradigmatis. Yogyakarta: pustaka pelajar

Musvitasari, Nike Amalia. 2017. "Keefektifan Model Pembelajaran Bamboo Dancing Untuk Meningkatkan Hasil Belajar Siswa Dalam Pembelajaran Matematika Kelas V SD Negeri Mlatiharjo 02 Semarang”. Skripsi : Universitas PGRI Semarang.

Nurseto, Tejo. 2011. Membuat media pembelajaran yang menarik. http://perpus.umpalangkaraya.ac.id/digilib/files/disk1/4/123-dfadf-deawahyuca-180-1-skripsii.pdf. Diakses pada tanggal 12 November 2018.

Rusman.2014.Model-Model Pembelajaran Mengembangkan Profesionalisme Guru.Jakarta: bajagrafindo persada

Santiva, Denianto Yoga.2012.Penggunaan media kartu untuk meningkatakan hasil belajar geografi siswa $\begin{array}{llllll}\text { kelas } & X I & \text { IPS } & 1 & \text { SMA } & \text { Kolombo }\end{array}$ Yogyakarta.http://eprints.uny.ac.id/23389/1/jurnalpenggunaan\%20media\%20kartuhasilbelajar.pdf. Diakses pada tanggal 17 Januari 2019 
Soegeng, A. Y.2017.Filsafat Pendidikan. Yogyakarta: Magnum Pustaka Utama.

Shoimin, Aris.2014.68 Model Pembelajaran Inovatif dalam Kurikulum 2013 . Yogyakarta: ar-ruzz media.

Sugiyono.2017.Metode Penelitian Pendidikan (Pendekatan Kuantitatif, Kualitatif, dan R\&D).Bandung: Alfabeta.

Sudjana.2005.Metoda Statistika.Bandung: Tarsito.

Susanto, Ahmad.2016.Teori Pembelajaran di Sekolah Dasar.Jakarta: prenadamedia group

Slameto.2013.Belajar Dan Faktor-Faktor Yang Mempengaruhi.Jakarta: rineka cipta

Susilana, Rudi\&Riyana, Cepi.2017.Media Pembelajaran (Hakikat, Pengembangan, Pemanfaatan, dan Penilaian).Bandung: wacana prima

Suprijono, Agus.2016.Cooperative Learning Teori \& Aplikasi Paikem.Yogyakarta: pustaka pelajar.

Sudjana, Nana.2010.Penilaian Hasil Proses Belajar Mengajar.Bandung: Remaja Rosdakarya Offset 